\title{
Adaptation of irrigated agriculture to climate change: trans- disciplinary modelling of a watershed in South India
}

\author{
L. RUIZ ${ }^{1,2,3}$, M. SEKHAR ${ }^{3,4}$, A. THOMAS ${ }^{5}$, S. BADIGER ${ }^{6}$, J.E. BERGEZ ${ }^{7}$, S. BUIS ${ }^{8}$, \\ S. CORGNE ${ }^{9}$, J. RIOTTE ${ }^{3,10}$, H. RAYNAL ${ }^{11}$, S. BANDHYOPADHYA ${ }^{12}$ \& \\ C. GASCUEL ${ }^{1,2}$ \\ 1 INRA, UMR SAS, Rennes, France \\ ruiz@rennes.inra.fr \\ 2 Agrocampus Ouest, UMR SAS, Rennes, France \\ 3 Indo-French Cell for Water Sciences, IRD-Indian Institute of Science, Bangalore, India \\ 4 Indian Institute of Science, Department of Civil Engineering, Bangalore, India \\ 5 INRA, LERNA, Toulouse School of Economics, Toulouse, France \\ 6 ATREE, Ashoka Trust for Research in Ecology and the Environment, Bangalore, India \\ 7 INRA, UMR AGIR, Toulouse, France \\ 8 INRA, UMR EMMAH, Avignon, France \\ 9 LETG, COSTEL, Univ. Rennes 2, Rennes, France \\ 10 IRD, GET, Toulouse, France \\ 11 INRA, UMIAT, Toulouse, France \\ 12 ISRO, Headquarters, Bangalore, India
}

\section{INTRODUCTION}

In the context of climate change and of agriculture increasingly relying on groundwater irrigation, it is crucial to develop reliable methods for sustainability assessment of current and alternative agricultural systems. The awareness that water resource management must account for interactions and feedbacks between biophysical processes determining the movement of water and human behaviour in a given socio-economic context, has gained significant recognition among scientists in the past few years, including the recent advocacy for the development of the new science of "socio-hydrology", dedicated to studying the "co-evolution of coupled human-water systems" (Sivapalan et al. 2011). Recently, "Change in hydrology and society" was proposed by IAHS as the main research theme for the decade 2013-2022 (Montanari et al. 2013).

A wide variety of models have been developed for simulating future scenarios of land-use change, climate change or ex-ante evaluation of management policies. Such models usually fail to account for feed backs of shrinking water resources on farmer strategies, and tend to neglect the biophysical and socio-economic interactions occurring both spatially and temporally, within the watershed (Barthel et al. 2012).

We introduce the Indo-French CEFIPRA project "AICHA" (Adaptation of Irrigated agriculture to climate CHAnge, 2013-2016) based on a watershed in South India where a longterm environmental observatory has been set-up. We describe the trans-disciplinary approach that is being developed to analyse the agro-hydrological and socio-economic drivers of groundwater sustainability and farmer adaptation, using integrated modelling.

\section{STUDY SITE AND PROBLEMS}

The Berambadi watershed $\left(84 \mathrm{~km}^{2}\right)$ belongs to the South Gundal basin (Fig. 1(a)), $816 \mathrm{~km}^{2}$, part of the Kabini River basin (southwest of Karnataka). Regionally, the climate is dominated by a monsoon regime that generates a strong precipitation gradient with decadal trends and strong interannual variability, with recurrent droughts (Sekhar et al. 2011).

The site has been developed as a research observatory since 2002 by the Indo-French Cell of the Water Science Cell (LMI IFCWS - IISc/IRD) in Bangalore. The site is recognized as an Environmental Research Observatory (ORE) (http://bvet.omp.obs-mip.fr). Socio-economic surveys were carried out as a part of the AICHA project. Further details can be found at http://ambhas.com/.

The groundwater levels display a pattern that is non-classical hydrogeologically, the valley regions having deeper groundwater levels than the topographically higher zones. This pattern 
(a)

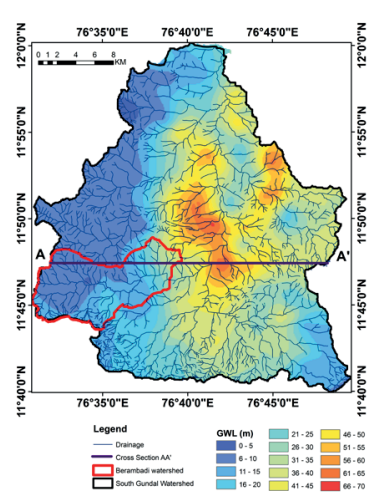

(b)

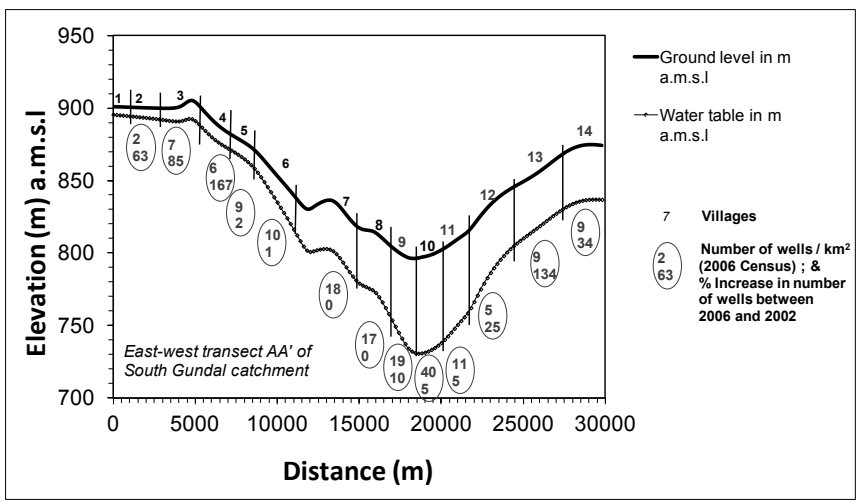

Fig. 1 Illustration of data acquisition in the South Gundal watershed: (a) stream drainage and depth to groundwater levels (obtained using about 600 disused bore wells); (b) topographic elevation (in $\mathrm{m}$ a.m.s.l.) and water table level along the transect AA'.

results from intensive groundwater pumping in the villages in valley that started in the early 1990s. The decline in groundwater level provoked the disconnection between the groundwater and the river bed, and the main permanent rivers turned into ephemeral streams. Wells have recently been drilled in the upland areas and groundwater irrigation is increasing. Our analysis suggests that these contrasted evolutions are closely linked to the spatial distribution of soil type and groundwater availability, besides access to market and knowledge.

\section{TRANS-DISCIPLINARY MODELLING}

A model framework is presented that combines modules of hydrology, crop, economics and a farmer decision module that accounts for strategic choices by farmers at different time scales and is governed by decision rules, which allow the representation of adaptation by farmers to a changing environment. It is developed on the RECORD platform (Bergez et al. 2013). The hypotheses are:

- The system is governed by the interactions and feedbacks between crop growth, water resource availability and socio-economic components.

- The system is driven by the spatial variations of all its components and the spatial interactions and feedbacks play a major role, especially in hard rock aquifers possessing low water storage and complex spatial recharge mechanisms.

One of the challenges of using such models for scenario testing in a distributed way is the need for accurate knowledge, for example of soil and crop parameters (Launay and Guérif 2005) which are scarcely available for tropical conditions. As an example of the development of innovative methodologies fostered by the project, we have presented a method to retrieve soil parameters using remote sensing and crop model inversion (Sreelash et al. 2012, 2013).

Acknowledgements We thank all the project members and the technical team. In addition to the funding from IFCPAR (Indo-French Center for the Promotion of Advanced Research) through the AICHA project (4700WA), work is supported by IRD, Embassy of France in India, INRA and IISc.

\section{REFERENCES}

Barthel, R., et al. (2012) Water Resource Management 26:1929-1951

Bergez, J.-E., et al. (2013) Environmental Modelling \& Software, 39, 39-49.

Launay, M. and Guérif, M., (2005). Agriculture, Ecosystems and Environment, 111, 321-339

Montanari, A., et al. (2013) Hydrological Sciences Journal, 58(6), 1256-1275.

Sekhar, M., et al. (2011) In: Findkakis, A.N. and Sato, K. (eds.) Groundwater Management Practices. IAHR Monograph. ISBN: 9780415619875 . Chapter 5.

Sreelash, K., et al. (2012) Journal of Hydrology 456-457, 57-67.

Sreelash, K., et al. (2013). Journal of the Indian Institute of Science 93(2), 189-207.

Sivapalan, M., et al. (2012) Hydrological Processes 26, 1270-1276. 